\title{
BERBAGAI ISU KRISTOLOGIS: TANTANGAN UNTUK GEREJA MASA KINI ${ }^{1}$
}

\author{
Petrus Maryono* \\ email: petruswongyogya@gmail.com \\ Sekolah Tinggi Teologi Injili Indonesia
}

\begin{abstract}
This article aims to discuss the various Christological issues related to the person and nature of His work. Beginning with Christological doctrine as the center of struggle that has been discussed from the early centuries and ends with the development of contemporary teaching which still left a misconception of the person and work of Jesus. The scholars discussed in this article have produced errors which, when examined at the root of the Christological problem, are at the refusal of the Scriptures as the supreme authority and the only basis for the development of theological teaching, and the use of secular philosophy or influential philosophical teachings when it is so easy contaminating the development of Christology. In relation to the many contemporary teachings that make many mistakes, it is suggested that we study and critically examine all the claims made. Second, we must look at the techniques of argumentation and interpretation they use. Three discover what philosophical approaches are used in the understanding of Christology.
\end{abstract}

Key Words: Christology, interpretation, controversial, philosophical approaches

*PETRUS MARYONO, TH.M., PH.D (Dallas Theology Seminary, Dallas, Texas, USA) adalah dosen dan pakar Perjanjian Baru di Sekolah Tinggi Teologi Injili Indonesia.

${ }^{1}$ Pernah disajikan dalam acara seminar Kristologi di STAKPN Tarutung, tanggal 14 Nopember 2016. 


\section{Pendahuluan}

Selaras dengan posisinya sebagai pusat iman Kristen, doktrin Kristologi telah menempati pusat pengajaran gereja sejak awal. Berbagai wujud usaha awal perumusan doktrin ini ditemukan di sepanjang Perjanjian Baru. Meski bentuknya sederhana, tidak selalu diungkapkan dengan cermat, tetapi inti terpenting keyakinan gereja purba tentang doktrin ini cukup jelas. ${ }^{2}$ Namun harus diakui, usaha untuk memahami doktrin Kristologi tidak pernah mudah, bahkan ketika penelitian didasarkan pada data dalam Perjanjian Baru. ${ }^{3}$

Pribadi Kristus memang enigmatik, tak terkecuali hakikat karyaNya. Karena itu, ketika ada ajaran palsu muncul dan mulai berkembang, salah satu target utama serangannya terarah kepada Kristologi. Para pemimpin gereja biasanya cepat tanggap terhadap keributan tersebut, sehingga pertemuan resmi gereja segera diselenggarakan. Pertemuan seperti itu biasanya menghasilkan sebuah kesepakatan, semacam manifesto keyakinan Kristologi, yang walaupun tidak sempurna, tetapi mencerminkan kejelian mereka dalam memahami ajaran Alkitab yang paling mendasar tentang dokrin ini.

Terjadinya Reformasi Protestan mengawali dan menggulirkan kebebasandan usaha berteologi dalam cara yang tidak pernah terjadi sebelumnya. Dalam prosesnya, perpaduan antara penghargaan tinggi

${ }^{2}$ Misalnya, Filipi 2:1-1; band., 1Tim. 3:16, 2Tim. 3:11-13.

${ }^{3}$ Diskusi bermanfaat untuk masalah ini, cermati I. Howard Marshall, The Origins of New Testament Christology, edisi disempurnakan (Downers Grove, IL: Intervarsity Press, 1990). Juga, Oscar Culmann, The Christology of the New Testament, ed. rev. (Filadelfia: Westminster Press, 1963). Khusus untuk masalah doktrin inkarnasi, selidiki James D. G. Dunn, Christology in the Making: A New Testament Inquiry into the Origins of the Doctrine of the Incarnation, ed. Ke-2 (Grand Rapids: Wm. B. Eerdmans, 1980). terhadap kecukupan rasio manusia sebagai ukuran kebenaran dan penolakan untuk menaklukkan diri terhadap tradisi atau tatanan baku, mewarnai diskusi, tak terkecuali ketika masalah Kristologi menempati pusat percakapan. Keadaan ini terus berlanjut, semakin lama semakin seru dan canggih, dan belum ada gejala untuk berhenti, dan napmpaknya akan terus bergulir, dan mungkin saja hingga waktu yang melampaui masa hidup kita semua.Jika hal itu benar adanya, maka gereja (dan para pemimpin gereja) berkewajiban untuk memahami pergolakan ini, kemudian menyikapi semua itu dengan bijak.

\section{Pada Mulanya}

Pengamatan terhadap keyakinan para tokoh gereja mula-mula menunjukkan bahwa ketepatan dan kejelasan dalam menyajikan gagasan, bukan ciri yang menonjol. Para penulis masa itu hanya puas dengan mengutip dan menampilkan ayat-ayat Firman Tuhan untuk melandasi ajarannya, tanpa menyertakan tafsiran memadai terhadapnya. Mereka belum terlalu peduli untuk berteori atau menyuguhkan uraian rinci terhadap teks yang digunakannya. Barangkali salah satu sebab dari gejala ini, saat itu mereka belum menghadapi serangan ajaran sesat yang cukup berarti, sehingga kepedulian sangat terarah kepada masalah yang terkait dengan hidup Kristen praktis (hal ini tercermin, misalnya dalam Didakhe, Surat Gembala dari Hermas, dan lainnya). Tidaklah mengherankan bila para tokoh itu belum mengembangkan teknik tafsir (hermenutik) yang memadai, dan cukup puas mengutip Kitab Suci begitu saja untuk landasan berbagai pengajaran yang disajikannya. ${ }^{4}$

${ }^{4}$ Literatur yang relevan untuk ini, tersedia dalam karya J. B. Lightfoot, The Apostolic Fathers, ed. J. R. Harner (Grand Rapids: Baker Book House, 1987). 
Namun gejolak segera terjadi, ketika sejumlah ajaran menyimpang mulai bermunculan di kalangan orang percaya. Gereja purba sesungguhnya telah menghadapi benih-benih kesesatan semacam itu. Namun Rasul Kristus masih hidup untuk mendampingi, sehingga dampak negatif dari gejala tersebut relatif masih terkendali. Ketika pertumbuhan ajaran menyimpang makin formal dan gencar, keadaannya mulai berbeda. Tampilnya ajaran menyimpang seperti Ebionitisme, Marcionisme, Arianisme, dan Apollinarianisme, dan sejenis, dengan hebat menggoncang gereja, akhirnya memaksa gereja untuk merumuskan keyakinan Kristologinya, siapa Kristus itu sesungguhnya, demikian juga berbagai aspek yang terkait dengan itu. ${ }^{5}$

\section{Tanggapan Gereja}

Oleh kontroversi ini lahirlah sejumlah pemikir luar biasa. Sumbangan pikiran mereka bermuara pada deklarasi iman yang dihasilkan dalam pertemuan resmi gereja di kota Nikea (tahun 325). Intinya, pengakuan itu menegaskan bahwa Yesus sehakikat dengan Bapa, Yesus itu Allah sejati-manusia sejati, kedua sifat menyatu dengan sempurna dalam satu pribadi, tanpa berakibat pada percampuran, pencemaran, atau pengurangan kemurnian masing-masing sifat tadi.

Dengan sesungguhnya, rumusan yang disajikan dalam konsili tersebut telah berhasil menampilkan ajaran Alkitab tentang pokok Kristologi dengan cukup memadai.Keberhasilan mereka bersumber pada beberapa faktor; yang terpenting adalah berikut ini: (1) Penerimaan dan penempatan Kitab Suci sebagai otoritas tertinggi. Kristologi mereka adalah buah penggalian dan pergumulan serius Kitab Suci., dan tidak mengijinkan sumber di luar itu menjadi

${ }^{5}$ Tentang hal ini, cermati Louis Berkhof, History of Doctrine (Grand Rapids: Baker Book House, 1937). landasan pembangunan doktrin. (2) Kesediaan untuk mengakui keberadaan mujizat dan intervensi ilahi dalam perumusan teologi. Karena itu, mereka bersedia menaklukkan rasio kepada wibawa penyataan ilahi. (3) Keterbukaan untuk menerima 'tradisi,' yang diwariskan oleh para tokoh dan pemikir gereja yang mendahului. Mereka tidak menerimanya dengan membabi buta, tetapi terlebih dahulu menyaring dan mengujinya dengan Kitab Suci (sebagai ukuran tertinggi). (4) Keberanian untuk hidup bersama paradoks dan menerima kebenaran yang tidak selalu dapat dijelaskan untuk memuaskan rasionya. Sikap ini memungkinkan terpeliharanya keseimbangan antara iman dan rasio dalam keyakinan doktrinalnya.

Namun ada satu masalah penting di sini. Gereja tidak selalu merumuskan doktrinnya dengan tegas dan cermat. Dalam rumusan yang dihasilkannya, mudah dikenali adanya kemenduaan arti, atau celah untuk memasukkan unsur baru ke dalamnya, sehingga rentan untuk mengubah gagasan yang disajikan, yang bisa saja jauh menyimpang dari yang semula dimaksudkan. Kenyataan inilah yang kemudian melahirkan berbagai penyimpangan baru, dan menjadikan masalahnya semakin kompleks. Kenyataan seperti itu terlihat jelas dengan munculnya berbagai perdebatan Kristologis setelah pertemuan Nikea itu, yang fokusnya terarah kepada berbagai aspek yang belum disajikan dengan rinci dan cermat dalam rumusan konsili tadi. ${ }^{6}$

\section{Akar Keruwetan}

Pemimpin gereja menabur benih masalah, yang dengan cepat berubah menjadi badai, ketika mereka memutuskan untuk melenyapkan Galileo-Galilei, sebab meyakini bahwa ajaran tokoh ini berseberangan dengan fatwa gereja. Klaim bahwa gereja pemegang monopoli kebenaran, terlebih

\footnotetext{
${ }^{6}$ Untuk mencermati diskusi tentang topik ini, perhatikan Ibid., 102-113.
} 
ketika Kitab Suci disikapi sebagai diktat ilmu dan teknologi, keruwetan besar mulai berkecamuk. Keruwetan yang lebih besar lagi segera terjadi, ketika pemikir gereja mulai menaklukkan Kitab Suci di bawah otoritas ilmu dan teknologi. Manakala Alkitab tidak lagi dinilai berbeda dengan karya sastera lainnya, dan dimensi keilahian Firman Tuhan secara radikal ditanggalkan, maka revolusi teologi telah menjadi realita. Teologi berubah menjadi menjadi antropologi, sebuah kegiatan untuk merumuskan aturan hidup beragama (etika) agar selaras dengan lingkungan hidupnya.

Dampaknya terhadap pemikiran Kristologi juga nyata. Kristologi tinggi bergeser ke Kristologi rendah. ${ }^{7}$ Kristus adalah manusia sejati, tetapi bukan Allah sejati. Yesus masih luar biasa, tetapi secara prinsip Ia sama sekali tidak beda dengan manusia lainnya. Khususnya, perbedaan Yesus dengan manusia lainnya hanyalah pada kadar, bukan pada hakikat. Karena itu, nilai Yesus bagi manusia hanyalah sebatas model, contoh, atau atas pengaruh ajaran-Nya. Sekali lagi, Yesus memang hebat, tetapi Ia sama dengan manusia pada umumnya dalam segala hal. Ia juga takluk kepada permasalahan apa pun, yaitu masalah yang dihadapi oleh manusia pada umumnya. Selanjutnya diyakini juga bahwa dalam menanggapi masalah itu, Yesus akan bereaksi, mengambil sikap, dan membuat keputusan, sama persis

\footnotetext{
${ }^{7}$ Berkhof telah mengamati bahwa abad ke-19 penelitian Kristologi ditandai oleh menguatnya tekanan pada sifat keinsanian Yesus, dan semakin memudarnya penghargaan terhadap sifat keilahian-Nya: "The point of view was anthropological, and the result was anthropocentric." Pendekatan seperti itu, tegasnya lebih lanjut, bermuara pada perubahan sikap mendasar dalam penelitian: "the new method was employed in such a manner as to yield destructive rather than conctructive results, Its application went hand in hand with strong aversion to authority and supernatural, and with insistent appeal to reason and experience." Ibid., 117, 118.
}

dengan yang dilakukan oleh manusia pada umumnya.

\section{Perkembangan Lanjut dan Situasi Pada Saat Ini}

Bila penyimpangan ajaran Kristologi terbentuk oleh salah satu atau gabungan dari sikap-sikap berikut: penyangkalan keilahian-Nya; penyangkalan keinsanian-Nya; atau (3) salah paham terhadap keberadaan dan penyatuan kedua sifat tersebut di dalam penjelmaan-Nya.

Gereja masa ini telah digoyang oleh munculnya sejumlah buku yang iktikadnya menyuarakan doktrin Kristologi. Beberapa yang paling populer adalah The Davinci Code (karya Dan Brown), The Jesus Dinasty (karya James Tabor), dan Makam Keluarga Yesus (karya Simcha Jacobivici dan Charles Pellegrino). ${ }^{8}$ Aspek yang dibahas oleh masing-masing buku itu berbeda, tetapi fokus utamanya sama; yaitu, menegaskan bahwa Yesus manusia biasa, tak ada bedanya dengan kita semua. Para penulis buku itu juga yakin bahwa Kristologi gereja saat ini keliru, dan dianggap sebagai upaya pelestarian pandangan hasil konspirasi pemimpin gereja dan penguasa politik masa lampau. Karena itu, gereja harus merevisi Kristologinya. Bukan itu saja, karena Kristologinya keliru, kekristenan secara keseluruhan juga dalam kondisi yang sama. Jadi, kekristenan juga membutuhkan hal serupa (i.e., perlu

\footnotetext{
${ }^{8}$ Evaluasi terhadap pemikiran dalam karya-karya tersebut dan yang sejenis, dapat diperhatikan dalam tulisan Craig A. Evans (Merekayasa Yesus), sebagaimana akan disinggung dalam bagian lanjut tulisan ini. Untuk ulasan terhadap karya James Tabor (The Jesus Dinasty) dan Simcha Jacobivici \& Charles Pellegrino (The Jesus Family Tomb/Makam Keluarga Yesus), tersedia dalam karya Adji A. Sutama, Yesus Tidak Bangkit?: Menyingkap Rekayasa Yesus Historis dan Makam Talpiot (Jakarta: BPK Gunung Mulia, 2007).
} 
direvisi dan dikembalikan ke jalur yang semestinya). Protes dan perjuangan para penganut "gnostisisme modern" menggerakkan idea ini, terlihat misalnya dengan pernah populernya Injil Yudas. ${ }^{9}$ Diduga bahwa kebenaran yang diungkap dalam naskah ini mengjungkirbalikkan teologi Kristen tradisional, karena berbeda mendasar dengan yang diajarkan oleh keduabelas rasul Kristus. Kenyataannya, Ireneus seawal tahun 180 $\mathrm{M}$ telah menyatakan ajaran ini sebagai bidat. ${ }^{10}$

Namun apa yang disuarakan oleh buku-buku di atas sama sekali bukan barang baru atau revolusioner. Pada masa lalu, sejumlah pemikir/teolog pada abad sembilan belas F. Schleiermacher, R. Bultmann, David Strauss, dan masih banyak lagi, telah melontarkan keyakinan yang sama. Hanya saja, pemikiran semacam itu pada awalnya hanya berpengaruh Eropa, kemudian menyebar ke Inggris dan Amerika, tetapi akhirnya menjamah pula seluruh panggung teologi dunia. Yang perlu dicatat, suara-suara itu disajikan dalam bungkus ilmiah dan sangat serius, sehingga dampak utamanya hanya menyentuh kalangan teolog dan akademisi dan tidak secara langsung menjamah warga gereja biasa.

Ada sejumlah perkembangan lebih baru, yang perlu disebut dan dicermati. Paul F. Knitter, melalui karyanya No Other Name? telah meletakkan landasan bagi pemikiran pluralisme agama dan soteriologi inklusivisme. 11 Sebagai sebuah

${ }^{9}$ Diskusi serius tentang masalah ini dapat disimak dalam Rodolphe Kasser, Marvin Meyer, dan Gregor Wurst, peny., Injil Yudas dari Kodeks Tsachos (Jakarta: Gramedia Pustaka Utama, 2006).

${ }^{10}$ Ibid., 146-47.

${ }^{11}$ Karya ini ditulis tahun 1985 . Sejak itu Knitter sudah menuangkan gagasannya dalam sejumlah karya lain, dan salah satu di antaranya bahkan berjudul Without Budha I Could Not Be a Christian (Oxford: Oneworld Publication, 2009, Tanpa Budha Aku Mustahil Menjadi Seorang Kristen), yang menunjukkan betapa ia memang seorang pluralis sejati. penyederhanaan, berikut inti pemikiran Knitter. Ia memulai dengan penegasan bahwa Allah yang maha dalam segala perkara, mustahil membatasi penyataanNya. Mengurungnya di dalam Alkitab, dan gereja, mengerdilkan Allah dan kehendak-Nya. Penyataan Allah, dan kebenaran sejati, muncul dan diawetkan dalam semua agama dunia. Karena itu, jalan keselamatan tidak tunggal, tetapi plural. Pernyataan Petrus bahwa Yesus adalah satu-satunya jalan keselamatan (Kis. 4:12) hanyalah sebuah refleksi pengalaman pribadi yang lahir dari pergumulan keagamaannya, sehingga tidak mewakili kebenaran normatif yang berlaku secara universal. Dampak Kristologinya, Yesus bukan satu-satunya Juru Selamat; Dia melainkan hanyalah sebuah nama untuk itu. Di luar Dia terdapat banyak nama lain yang sama sahnya dalam mengantarkan kepada penemuan keselamatan sejati. Pemikiran dasar seperti itu tentu saja secara langsung mempengaruhi pemahaman Knitter tentang misi dan penginjilan, demikian juga sikapnya terhadap agamaagama di luar kekristenan. ${ }^{12}$

Untuk meresponi berbagai pandangan yang disebutkan itu, Craig A. Evans menyuguhkan sebuah karya tulis yang telah mendapat pujian dari berbagai pihak. ${ }^{13}$ Evans memokuskan paparan dan evaluasinya terhadap ajaran kelompok Seminar Yesus (Jesus Seminar) dan ajaran tokoh-tokoh yang lebih kemudian. Evans melihat, akar dari berbagai ajaran Kristologi keliru berada pada penolakan Alkitab sebagai Firman Allah. Penyimpangan semakin jauh, ketika materi ekstra-biblika, terlebih materi yang berasal dari masa jauh setelah era gereja pertama, dijadikan sebagai dasar perumusan. Praktek ini

\footnotetext{
${ }^{12}$ Ia menuangkan gagasan ini dalam Jesus and the Other Names: Christian Mission and Global Responsibilty (Maryknoll, New York: Orbis Books, 1996).

${ }^{13}$ Craig A. Evans, Merekayasa Yesus: Membongkar Pemutarbalikan Injil oleh Ilmuwan Modern, pen. Johny The, peny. Eva Yunita (Yogyakarta: Andi Offset, 2007).
} 
terlihat, misalnya melalui pemanfaatan Injil ekstra-kanonik atau materi sejenis untuk tujuan tersebut. ${ }^{14}$

Perkembangan lain yang layak dicermati adalah pemikiran Eric H.H. Chang. ${ }^{15}$ Permasalahan utama yang menandai pemikiran tokoh ini adalah penekanan ekstrim terhadap ketunggalan Allah (monoteisme) dan penolakan (ekstrim, juga) terhadap konsep trinitas. Selaras dengan itu, Chang juga menolak atau menyangkali keilahian Yesus. Meski demikian, ia mengakui Yesus manusia hebat, panutan dalam banyak hal, tetapi bukan Allah, dan karena itu bukan objek penyembahan. ${ }^{16}$ Apakah Yesus Juru Selamat? Ya, tetapi bukan karena Ia adalah Allah yang menjelma menjadi manusia, ${ }^{17}$ tetapi karena Ia adalah manusia yang sempurna, bahwa kemuliaan Allah tampak pada wajahNya. Melalui kematian manusia seperti ini, maka "Yahweh telah mendamaikan

\footnotetext{
${ }^{14}$ Ibid., 47-79. Analisis Evans terhadap materi/literature ekstra-kanonik yang lain, dapat dicermati dalam Craig A. Evans, Noncanonical Writings and New Testament Interpretation (Peabody, MA: Hendrickson Publishers, 1992).

${ }^{15}$ Pemikiran Chang ditampilkan oleh Bentley C.F. Chan dalam Sebuah Kajian Monoteisme Alkitabiah, pen. Joanna Cakra dan Lewis Tak-Cham Chan (Semarang: Borobudur Publishing, 2011) dan Kemuliaan Allah pada Wajah Yesus Kristus, pen. Suah Choo Chuang, peny. Vera Wirawan dan Lew Ai Su (t.k.: Cahaya Pengharapan Ministries, 2015).

${ }^{16}$ Penekanan kepada keinsanian Yesus dan penolakan kepada keilahian-Nya menjadi tema dominan karya ini - lihat, Kemuliaan Allah, 385-88. Salah satu ciri menonjol dalam karya ini adalah penelitian cermat terhadap teks-teks Alkitab untuk melandasari argumentasi. Keakraban pandangan penulis dengan ajaran Socinus (leluhur Unitarianisme) sangat terlihat, di mana pemutlakan monoteisme telah menelan kesediaan untuk mengijinkan adanya Trinitarian dalam keallahan.

${ }^{17}$ Bandingkan masalah ini dengan pemikiran Anselmus dari Canterbury mengenai penebusan bertitiktolak dari penjelmaan Kristus, yang disarikan dalam ungkapan populer Cur Deus Homo - Berkhof, History of Doctrine, 171-72.
}

dunia dengan diri-Nya (2Kor. 5:1920).",18

Perkembangan lain yang harus dicermati juga, pemikiran khas yang disuarakan oleh Joseph Prince, Pendeta gereja New Creation di Singapura. ${ }^{19}$ Penekanan dalam pemikiran Prince adalah pada pemutlakan anugerah sebagai dasar keselamatan dan hidup Kristen. Sedemikian ekstrim penekanan itu, sehingga ajarannya dikenal dengan acuan "gerakan hiper-anugerah" (Inggris: hyper-grace). Bagi Prince anugerah identik dengan Kristus, dan penerimaan Kristus dalam keselamatan membuka segala berkat, keberuntungan, dan kesejahteraan, baik rohani maupun materi. Dengan itu, ia yakin menerima Kristus menjadi kunci untuk "keberhasilan, keutuhan, dan kehidupan berkemenangan dengan tanpa susah payah."

Prince membangun teologinya dengan memutlakkan literatur Paulus, utamanya Galatia. Dalam pemahamannya, nilai pelayanan Yesus hanya sebatas sengsara dan kematianNya (i.e., sebagai dasar pengampunan dosa dan jaminan keselamatan). Hidup Yesus selama penjelmaan tidak dihargai - karena tidak memiliki nilai salvifik begitu juga, berbagai ajaran dan prinsip hidup yang dibagikan-Nya pada kurun waktu itu. Sama menonjolnya adalah

\footnotetext{
${ }^{18}$ Chan, Kajian Monoteisme, 507.

${ }^{19}$ Karya terkenal Joseph Prince berjudul Destined to Reign (Singapura: Joseph Prince Teaching Resources, 2007). Telah tersedia dalam bahasa Indonesia Ditentukan untuk Memerintah: Rahasia Keberhasilan, Keutuhan dan Kehidupan Penuh Kemenangan Tanpa Susah Payah, pen. 22 Media Pte. Ltd., peny. Paula Allo (Jakarta: Immanuel Publishing House, 2010. Prince mengawali pelayanannya sebagai penatua, dan penunjukannya sebagai gembala telah mengubah gereja yang beranggotakan sekitar 150 warga dalam waktu relative singkat bertumbuh menjadi 30.000 (bahkan mungkin, 35.000) anggota jemaat. Bersama dengan itu, Prince telah berubah menjadi pengkotbah internasional yang sangat dicari dan telah berkeliling ke berbagai negara di berbagai benua.
} 
penolakan terhadap Perjanjian Lama (khususnya, Taurat); penghargaan hanya diberikan sejauh peran Taurat sebagai penuntun kepada anugerah, tetapi tidak berkenaan dengan princip moral dan etikalnya. Sikap keras seperti inilah yang mendorong banyak pengamat menengarai gerakan ini mengembangkan sikap antinomianisme, sebagai pandangan hidup, bahkan dalam praktik. ${ }^{20}$

Kekhasan ajaran Prince telah menggulirkan polemik dan keprihatinan. Salah satu kajian cukup mendalam terhadap teologi Prince disajikan oleh Michael L. Brown. ${ }^{21}$ Brown menerima dan menghargai penekanan aliran ini terhadap masalah anugerah, tetapi ia menunjukkan sejumlah masalah serius yang melekat di dalamnya. Analisis Brown segera saja menggugah Paul Ellis, salah satu dari sekian nama, yang oleh Brown diacu sebagai penganut teologi Prince. ${ }^{22}$ Kedua tokoh ini menindaklanjuti perbedaan pendapatnya melalui artikel internet. Sesudah salingpertukaran pikiran di antara keduanya, Brown tetap yakin, masalah-masalah yang ditandainya sebagai kekeliruan aliran ini masih belum mendapat jawaban memuaskan. ${ }^{23}$

Grace Error,"

20“"Antinomianism and the Hyper

https://billmuehlenberg.com/2015/02/16/ antinomianism-and-the-hyper-grace-error/, diakses pada tanggal 3/10/2016.

${ }^{21}$ Kasih Karunia Overdosis:

Menyingkap Bahaya Kasih Karunia Modern, pen. Yorry Anderson Nathan dan Yahya Kristiyanto (Jakarta: Nafiri Gabriel, 2015).

${ }^{22}$ Injil Hiper-Anugerah, pen. Debby D'vora, peny. Debby D'vora (Jakarta: Light Publishing, 2015).

${ }^{23}$ "Dr. Ellis Underscores the Errors of

Hyper-Grace,"

https://askdrbrown.org/loibrary/dr-paul-ellisunderscores-errors-hyper-grace, diakses pada tanggal 10/9/2016.

Tinjauan sekilas terhadap isyu Injil Hiper-Anugerah dapat dicermati juga dalam Petrus Maryono, "Hypergrace: Tinjauan Sekilas," materi Simposium PASTI, 18-20 Oktober 2016, bertempat di Midtown Hotel, Jl. Basuki Rahmat no. 76, Surabaya.
Kalau begitu apa sumbangan penting Para penulis Kristologi kontemporer ini? Mereka berhasil mengemasnya dalam bungkus populer, yang mudah dicerna, sehingga dampaknya langsung menyentuh masyarakat orang percaya secara luas. Mereka memanfaatkan kejenuhan umat terhadap gereja dan kekristenan 'normatif' untuk menyajikan gagasannya; juga, eratnya cengkeram ilmu dan teknologi modern dalam sanubari masyarakat masa kini. Tak terkecuali, memanfaatkan juga kehausan penduduk dunia modern terhadap berita sensasional, dan kegilaannya terhadap segala sesuatu yang baru, khas, dan berbeda dengan yang biasa. Kecakapan retorika para penulis ini dalam mengungkapan keyakinan hanya semakin efisien saja dalam usaha menggiring pembacanya ke kubu yang mereka kehendaki.

\section{Pelajaran Untuk Kita}

Beberapa simpulan patut disuguhkan pada akhir percakapan ini. Yang akan disinggung di sini tentu saja tidak komprehensif, karena masih banyak aspek terkait dengan pokok bahasan yang belum disinggung di sini. Namun berikut inilah hal paling mendasar yang baik disampaikan dalam kesempatan ini.

Pertama, akar terpenting pemicu muncul kekeliruan Kristologi berada pada penolakan Kitab Suci (tulisan kanonik) sebagai otoritas tertinggi dan dasar satu-satunya sebagai pembangunan ajaran teologi. Pemilihan tulisan literatur non-kanonik (apokrip, pseudokrip, dan dokumen lainnya), cenderung bermuara pada perumusan konsep kristologis menyimpang, terlebih ketika data dari tulisan-tulisan itu dipakai untukmenilai dan melawan data dari Kitab Suci. Kenyataan ini mengingatkan pentingnya untuk menempatkan Kitab Suci di pusat iman kita, sehingga sebagai ajakan untuk 
memperbaharui komitmen kepada prinsip sola scriptura.

Kedua, filsafat sekuler atau ajaran filsafat yang sedang sangat berpengaruh saat itu mudah sekali mencemari pengembangan Kristologi. Harus diakui, filsafat dan teologi memiliki bidang garapan yang relative sama, sehingga hasil pemikirannya dapat saja agak tumpang tindih. Merembesnya temuan filsafat ke dalam teologi, potensinya besar sekali dan sudah terjadi. Pada masa lampau, telah terjadi penyusupan filsafat Helenisme klasik ke dalam usaha berteologi. Sejak era Reformasi, humanism, rasionalisme, dialektis, eksistensialis, dan masih banyak lagi, masing-masing aliran filsafat ini telah meninggalkan jejaknya di kancah teologi. Pada masa kini, teologi (dan Kristologi) harus berhadapan dengan garangnya pengaruh filsafat posmo dan sejenis.

Ketiga, dunia modern sangat tidak sabar dengan yang pelik dan rumit. Ilmu dan teknologi modern telah memanjakan penduduk bumi ini dengan berbagai kemudahan, kenyamanan, dan suguhan cepat saji (instant). Dalam wujudnya yang khas, dunia modern cenderung anti-intelektual dan lebih menyukai yang berbau emosional dan primordial. Ciri ini berpadu erat dengan subjektivisme, terobsesi dengan pragmatism, khususnya selalu resah dengan pergumulan "apa kontribusi semua ini" untuk dirinya, yaitu dalam menyumbang tercapainya kenyamanan dan kepuasan pribadi.

Keempat, usaha untuk pemahaman terhadap pribadi dan karya Kristus telah menjadi pergumulan orang percaya sejak masa awal gereja. Kristus dan karya-Nya menempati pusat iman, bahkan menentukan mati dan hidupnya kekristenan. Karena itu, pergumulan kristologis tak akan pernah berakhir; tiap-tiap kali pemikiran baru akan muncul dan gereja mustahil melarikan diri dari menghadapi gejala seperti ini.
Apa yang harus dilakukan manakala peristiwa seperti itu terjadi? Beberapa kita sarankan: (1) Pelajari dengan teliti, dan hadapi kenyataan itu dengan kepala dingin. Dengarkan yang dikatakan, tetapi kritisi klaim-klaim (dakuan-dakuan) yang mereka ajukan. (2) Cermati teknik argumentasi yang mereka pakai. Teristimewa, amati, adakah kebenaran Kitab Suci, dokumen kanonik, ditempatkan sebagai landasan dan sekaligus hakim akhir. Apakah dalam menafsirkan teknya, mereka menggunakan teknik yang benar (baku)? (3) Temukan filsafat dasar yang menggerakkan usahanya. Artinya, cermati dengan teliti fondasi landasan pembangunan Kristologi yang mereka tawarkan. Akhirnya, (4) jangan abaikan pentingnya untuk menjadikan temuan para tokoh gereja masa lampau sebagai bandingan. Hasil karya mereka tidak sempurna, atau bebas dari kesalahan, tetapi pemikiran mereka telah teruji oleh waktu.

\section{Kesimpulan}

Isu Kristologis tidak pernah usang untuk diperbincangkan. Mulai dari abad-abad awal isu tersebut terus digumuli bahkan hingga sekarang ini. Rumusan-rumusan teologis terus saja dihasilkan. Namun persoalannya menjadi rumit karena pandangan beberapa tokoh kontemporer yang disorot dalam paparan artikel ini telah menyisakan masalah doktrinal yang serius bagi gereja masa kini. Karena itu berdasarkan kajian terhadap ajaranajaran yang mengemuka di atas, ada beberapa kesimpulan yang penting disampaikan. Pertama, pentingnya berpegang teguh pada rumusan doktrinal yang mengakui secara penuh kemanusiaan dan keilahian Yesus berbasis pada data-data biblikal yang solid. Kedua, cermati teknik tafsir dan argumentasi yang dipakai para tokoh tatkala mengemukakan klaim-klaminya terhadap isu ini. Terakhir, telusuri dengan teliti penggunaan filsafat sekuler 
atau ajaran filsafat dibalik setiap

argumentasi-argumentasi teologis yang

dihasilkan 


\section{Bibliografi}

Berkhof, Louis. History of Doctrine. Grand Rapids: Baker Book House, 1937.

Brown. Michael L. Kasih Karunia Overdosis: Menyingkap Bahaya Kasih Karunia Modern, pen. Yorry Anderson Nathan dan Yahya Kristiyanto. Jakarta: Nafiri Gabriel. 2015.

Chan, C.F. Bentley. Sebuah Kajian Monoteisme Alkitabiah. Diterjemahkan oleh Joanna Cakra dan Lewis Tak-Cham Chan. Semarang: Borobudur Publishing. 2011.

Chang, Eric H. H. Kemuliaan Allah pada Wajah Yesus Kristus. Diterjemahkan oleh Suah Choo Chuang. Disuntingkan oleh Vera Wirawan dan Lew Ai Su. Jakarta: Cahaya Pengharapan Ministries. 2015.

Culmann, Oscar. The Christology of the New Testament, ed. rev. Filadelfia: Westminster Press. 1963.

Dunn, D.G. James. Christology in the Making: A New Testament Inquiry into the Origins of the Doctrine of the Incarnation, ed. Ke-2. Grand Rapids: Wm. B. Eerdmans. 1980.

Ellis, Paul. Injil Hiper-Anugerah, pen. Debby D'vora, peny. Debby D'vora (Jakarta: Light Publishing. 2015.

Evans, A. Craig. Merekayasa Yesus: Membongkar Pemutarbalikan Injil oleh Ilmuwan Modern. Diterjemahkan oleh Johny The. Disuntingkan oleh Eva Yunita. Yogyakarta: Andi Offset. 2007.

. Noncanonical Writings and New Testament Interpretation. Peabody, MA: Hendrickson Publishers. 1992.

https://billmuehlenberg.com/2015/02/16/ antinomianism-and-the-hyper-grace-error/, diakses pada tanggal 3/10/2016.

https://askdrbrown.org/loibrary/dr-paul-ellis-underscores-errors-hyper-grace, diakses pada tanggal 10/9/2016.

Knitter, Paul F. Jesus and the Other Names: Christian Mission and Global Responsibilty. Maryknoll, New York: Orbis Books, 1996.

Kasser, Rodolphe, Marvin Meyer, dan Gregor Wurst, peny. Injil Yudas dari Kodeks Tsachos. Jakarta: Gramedia Pustaka Utama. 2006.

Lightfoot. B. The Apostolic Fathers. ed. J. R. Harner. Grand Rapids: Baker Book House. 1987.

Marshall, I. Howard. The Origins of New Testament Christology. Downers Grove, IL: Intervarsity Press. 1990.

Maryono, Petrus. "Hypergrace: Tinjauan Sekilas." Materi disajikan dalam Simposium PASTI, 18-20 Oktober 2016. Surabaya. 2016.

Prince, Joseph. Destined to Reign. Singapura: Joseph Prince Teaching Resources. 2007.

Sutama A. Adji. Yesus Tidak Bangkit?: Menyingkap Rekayasa Yesus Historis dan Makam Talpiot. Jakarta: BPK Gunung Mulia. 2007. 